\title{
How Will Climate Change Affect Human Health?
}

Citation for published version (APA):

Martens, P. (1999). How Will Climate Change Affect Human Health? American Scientist, 87(6), 534-541. https://doi.org/10.1511/1999.42.839

Document status and date:

Published: 01/01/1999

DOI:

10.1511/1999.42.839

Document Version:

Publisher's PDF, also known as Version of record

Document license:

Taverne

\section{Please check the document version of this publication:}

- A submitted manuscript is the version of the article upon submission and before peer-review. There can be important differences between the submitted version and the official published version of record.

People interested in the research are advised to contact the author for the final version of the publication, or visit the DOI to the publisher's website.

- The final author version and the galley proof are versions of the publication after peer review.

- The final published version features the final layout of the paper including the volume, issue and page numbers.

Link to publication

\footnotetext{
General rights rights.

- You may freely distribute the URL identifying the publication in the public portal. please follow below link for the End User Agreement:

www.umlib.nl/taverne-license

Take down policy

If you believe that this document breaches copyright please contact us at:

repository@maastrichtuniversity.nl

providing details and we will investigate your claim.
}

Copyright and moral rights for the publications made accessible in the public portal are retained by the authors and/or other copyright owners and it is a condition of accessing publications that users recognise and abide by the legal requirements associated with these

- Users may download and print one copy of any publication from the public portal for the purpose of private study or research.

- You may not further distribute the material or use it for any profit-making activity or commercial gain

If the publication is distributed under the terms of Article $25 \mathrm{fa}$ of the Dutch Copyright Act, indicated by the "Taverne" license above, 
How Will Climate Change Affect Human Health? The question poses a huge challenge to scientists. Yet the consequences of global warming of public health remain largely unexplored

Author(s): Pim Martens

Source: American Scientist, NOVEMBER-DECEMBER 1999, Vol. 87, No. 6 (NOVEMBERDECEMBER 1999), pp. 534-541

Published by: Sigma Xi, The Scientific Research Honor Society

Stable URL: https://www.jstor.org/stable/27857937

\section{REFERENCES}

Linked references are available on TSTOR for this artigle:

https://ww jstor.org/stable/27857937?seq=1\&cid=pdf-

reference\#references_tab_contents

You may need to $\log$ in to JSTOR to access the linked references.

JSTOR is a not-for-profit service that helps scholars, researchers, and students discover, use, and build upon a wide range of content in a trusted digital archive. We use information technology and tools to increase productivity and facilitate new forms of scholarship. For more information about JSTOR, please contact support@jstor.org.

Your use of the JSTOR archive indicates your acceptance of the Terms \& Conditions of Use, available at https://about.jstor.org/terms 


\title{
How Will Climate Change Affect Human Health?
}

\author{
The question poses a huge challenge to scientists. Yet the consequences \\ of global warming for public health remain largely unexplored
}

\author{
Pim Martens
}

$\mathrm{O}$ ne hears a great deal about the ominous consequences of global warming-melting ice caps, rising sea levels, torrential floods, devastating droughts and severe harvest failuresbut one scarcely hears a word about the potential effects of climate change on public health. Such changes to the earth's surface will surely affect human life, but how? The answer is not a simple one, and there may be as much good in the forecast as there is bad. For the moment, we do not know where the balance lies.

Part of the reason the question has received so little attention is that it's so difficult to answer. The problem arises from the fact that climate change will affect human health in various parts of the globe in very different ways, often through complex changes in ecological systems. For example, the incidence of natural disasters-droughts, floods and violent stormsmay increase, but how severe will they be and where and when will they take place? And how do we quantify the consequences for human life? Does an extra foot of water correspond to a certain number of deaths? Surely this depends on whether it happens in a populated region and whether the community has the economic and technological means to respond to the crisis. What may be manageable for one region may be overwhelming for another. And not all of the changes will be for the worse. A general warming may actually be beneficial for human life in certain parts of the world, but where?

At the moment scientists do not have exact answers to these questions. We can only develop plausible scenarios with the hope that our attempts to anticipate the problems will lessen the possibility of tragedy. Consider this: If the the world's climate were to get progressively warmer, as some computer models suggest, tropical climates would likely expand beyond their current range. A warmer, more humid climate will improve the prospects for a number of the most deadly microorganisms, as well as for the rats, flies, mosquitoes and other vectors that spread these pathogens. There are other threats to human life brought on by climate change: heat stress, reduced air quality and malnutrition. Here I explore some of these possibilities and offer suggestions for a course of action.

\section{Heat Stress}

Perhaps the most immediate consequence of increasing global temperatures will be a rise in the number of heat waves and heat-related illnesses. Such temperature extremes can, for example, increase the sensitivity of asthmatics to their condition. There will also be an increasing number of deaths from heat stress brought about by high ambient temperatures lasting days on end. In populated urban areas the heat stress is further amplified by "heat islands," treeless concrete and asphalt neighborhoods, especially where the houses are poorly maintained and there is no air conditioning. During a typical heat wave in an urbanized country such as the Netherlands, for example, there is an excess death rate of a few dozen people per day. And the recent heat waves in the United States during the summer of 1999 took their heaviest tolls in urban areas. The victims are usually people with heart disease or lung infections, as well as children and the elderly.

A typical consequence of heat stress is sunstroke, where the body temperature rises above 41 degrees Celsius. The annual, week-long pilgrimage to Mecca-the Hajj-illustrates the effect of high temperatures in the absence of air conditioning. During the Hajj, the temperatures in Mecca typically range between 30 and 50 degrees. Since the pilgrims are tightly packed together in suffocatingly small spaces, their body temperatures climb rapidly. In hotter years there may be more than 10,000 incidents of heat-related illness among the pilgrims. In a typical year, approximately 2,000 people suffer sunstroke during the Hajj, and half of them die.

The reverse side of the coin is that the milder winters associated with global warming will offer a better chance of survival for at-risk groups such as the elderly during the coldest months. Research into the effect of a gradual temperature increase has revealed that we can expect a 


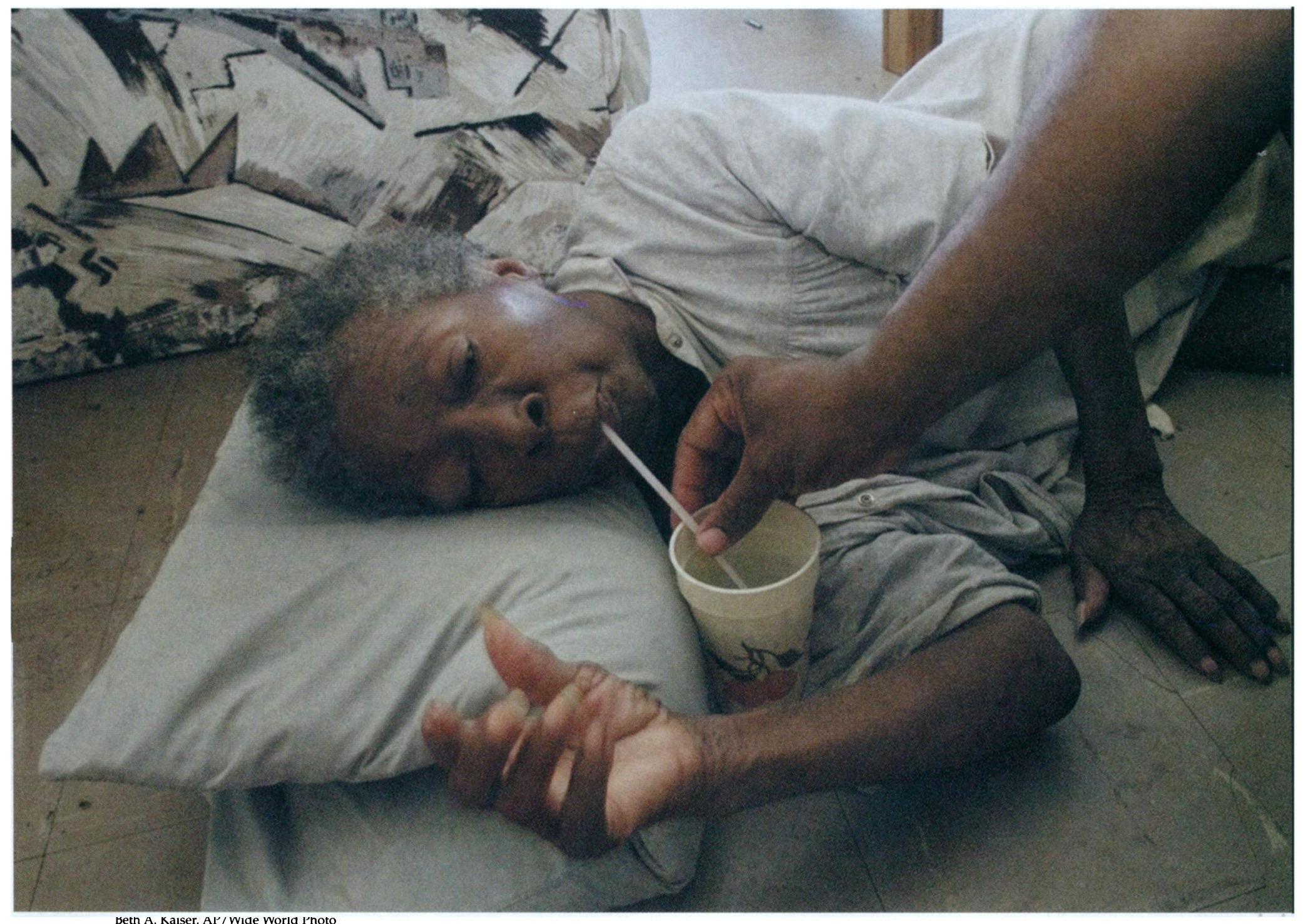

Betn A. Kaiser, AY' Wide World I'noto

Figure 1. High temperatures during summer heat waves place the greatest stress on the poor and the elderly. Here a heat-stricken woman in Chicago receives water during the summer heat wave of 1999 in North America. The incidence of heat waves may increase in future decades if current trends of global warming continue. The author discusses the effects of heat waves and the possible consequences of other climate changes for global public health.

decline in mortality from cardiovascular and pulmonary disease in the winter. Whether the milder winters could offset the mortality during the summer heat waves is one of the questions that demands further research.

\section{Air Quality}

Human health is also affected by increasing temperatures in more complex ways. For example, a number of studies in the U.S. have revealed that extreme temperatures and air pollution have a mutually reinforcing effect on illness. In other words, simultaneous exposure to heat and pollution appears to be more harmful than the sum of the individual effects. Accelerated formation of certain pollutants (such as ozone) during heat waves is well established, and this is likely to be part of the reason. The combustion of fossil fuels therefore has a twofold effect, as it is not only a major source of air pollutants; it is also one of the causes of the greenhouse effect.

Extreme weather conditions also decrease air quality in other ways. Allergenic pollens and spores are more readily dispersed during hot, dry summers. On the other hand, the house dust mite, whose feces contain a powerful allergen, flourishes in a humid environment. And the growth of molds is promoted during rainy summers. In the 1990s, an epidemic of coccidioidomycosis, or valley fever, broke out in the U.S. during a prolonged heavy rainfall that followed a drought. The fungus Coccidioides immitis can spread hundreds of miles by wind and infects people and animals when the dangerous spores are inhaled.

\section{The Spread of Infectious Diseases}

Climate is one of the factors that governs the occurrence of many infectious diseases, from the 


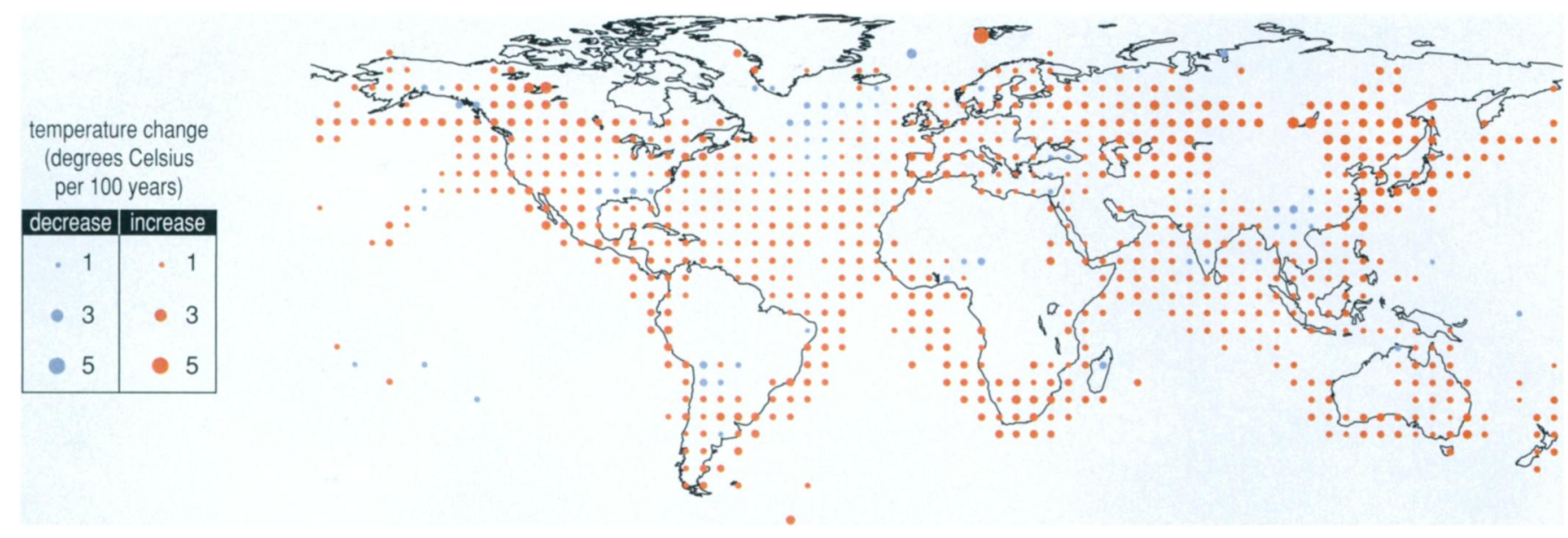

Figure 2. Trends in the average annual temperature between 1901 and 1998 indicate a general warming (red dots) during the 20th century, although a few regions have experienced some cooling (blue dots). (Adapted from IPCC 1998. Courtesy of the National Climatic Data Center.)

Black Death in 14th-century Europe to modern times when the spread of Ebola in Africa, cholera in South America and Lyme disease in the U.S. are affected by changes in temperature, rainfall, sunshine and even ocean currents. It is the interaction among these factors that will-in combination with other, non-climatic factors- determine the timing of infectious disease outbreaks. Most climate models suggest that the greatest temperature increase will be at higher elevations, in the winter and in the evenings. There will also be changes in the amount of precipitation, with some regions becoming wetter than they are now. Should tropical climates spread beyond their current limits, there is a good chance that tropical diseases will follow.

Below I offer several short descriptions of diseases whose prevalence will be affected by a changing climate. The brief list provided here could easily be expanded, for example, to include such diseases as onchocerciasis (river blindness), yellow fever and African trypanosomiasis (sleeping sickness), which is transferred by the tsetse fly.

\section{Malaria}

Malaria claims millions of lives every year, mainly in tropical Africa but also in large areas of South America and Southeast Asia. Malaria is caused by the malaria parasite, Plasmodium, and is spread by the Anopheles malaria mosquito, which serves as the vector of the disease. The female mosquito becomes infected with malaria if she sucks the blood of an infected person. The mosquito may then infect the next person she bites. The spread of the disease is thus limited by conditions that favor the vector and the parasite. The malaria mosquito is most comfortable at about 20 to 30 degrees and at a relative humidity of at least 60 percent. Furthermore, the malaria parasite develops more rapidly inside the mosquito as the temperature rises, and development ceases entirely below about 15 degrees. Increased rainfall and surface water also provide the breeding grounds for the mosquito. A climate change may thus wreak a considerable change on the distribution of the disease.

Malaria was quite common in the Roman Empire and in medieval Europe, and until a few
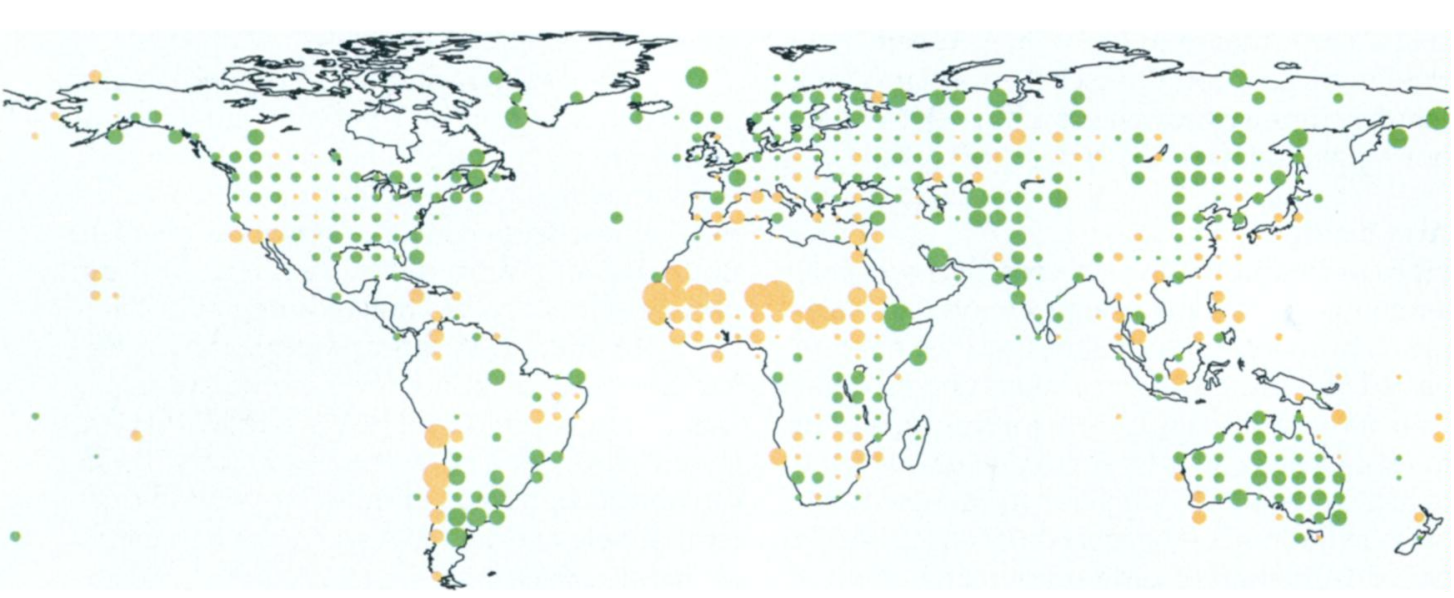

percent per 100 years) decrease increase

\begin{tabular}{|c|c|}
\hline 10 & $\cdot 10$ \\
20 & $\bullet 20$ \\
40 & 40 \\
\hline
\end{tabular}

Figure 3. Trends in the average annual precipitation on land between 1901 and 1998 indicate a general increase in wetness (green dots) during the 20th century, although some regions have become drier (brown dots). (Adapted from IPCC 1998. Courtesy of the National Climatic Data Center.) 
decades ago it was still present in parts of Europe, Australia and North America. Prior to 1945 , thousands of people became infected with Plasmodium vivax malaria in the Netherlands, mainly in the provinces of North Holland and Zeeland. In fact, the British invasion of Zeeland in 1806 failed to drive out the French troops because the majority of the British force was infected with malaria.

Although malaria has disappeared from most wealthy countries, partly due to the use of insecticides and the antimalarial medicine chloroquine, the mosquitoes that transfer the disease are still present. For that reason, and because increased air travel means that people are importing malaria from abroad every year, there is a permanent risk that a local epidemic may break out. In Europe the potential risk is greatest in the countries that surround the Mediterranean.

In fact, Italian scientists have recently discovered a case of malaria-the first in 20 years-where infection took place in Europe. A local species of mosquito infected a number of people by way of a girl who had acquired the disease abroad. Malaria was spread in a similar fashion in New York and New Jersey in this decade. The outbreak of such small, local epidemics is consistent with computer simulations that show an increased risk of malaria in temperate zones as the climate becomes warmer and more humid.

Tropical highlands, especially those on the African continent, are even more sensitive to a temperature rise. High altitude (with its lower temperatures) is one of the oldest defenses against malaria (and many other diseases). As early as the 16th century, European colonists in the New World built their houses at higher elevations. Even today many Ethiopian peasants who live in the lowlands seek out the highlands during the malaria season.

The elevation at which there is little or no malaria varies by region. In some countriessuch as Burundi, Ethiopia, Kenya, Morocco and Rwanda-the boundary is at about 2,000 meters. In other countries, such as Zimbabwe, this boundary is about 1,200 meters. Unfortunately, a minor temperature rise will be sufficient to turn the populated African highlands into an area that is suitable for the malaria mosquito and parasite. The situation will be further aggravated because the highland populations have little immunity to the disease.

The threat of malaria is currently increasing in other parts of the world. In 1997, malaria was reported in large areas of Papua New Guinea at an altitude of 2,100 meters. In the northwest of Pakistan, a mean temperature rise of about half a degree has probably played a major part in the increase of the number of cases of malaria from a few hundred at the beginning of the 1980 s to 25,000 in 1990 .

\section{Schistosomiasis}

Schistosomiasis, or Bilharzia, is another vectorborne disease that will be influenced by a changing climate. The enormous expansion of irrigation systems in many tropical countries has doubled the incidence of schistosomiasis in the past 50 years. Some estimates hold that nearly 200 million people are infected worldwide. The disease is caused by a parasitic worm whose eggs enter the water supply by way of human urine or feces. Infected water snails serve as hosts for the parasites while they develop into free-swimming "mini-worms." The circle closes when a mini-worm penetrates the skin of a person who comes in contact with the contaminated water. The worm continues its life cycle inside the human body, spreading to various organs and causing itching, fever, bloody urine and diarrhea (among other effects). Complications such as renal failure and hypertension may ultimately lead to death.

The development of the parasite and the snails are both governed by the ambient temperature, where warm waters favor their growth. And, of course, the warmer the ambient temperature, the more often people come into contact with water. Egypt is one of the countries that is likely to experience most of the effects of climate change on the spread of schistosomiasis. At the time of the pharaohs it was thought that both boys and girls menstruated, because nearly all children had blood in their urine from a schistosomiasis infection. In modern Egypt the
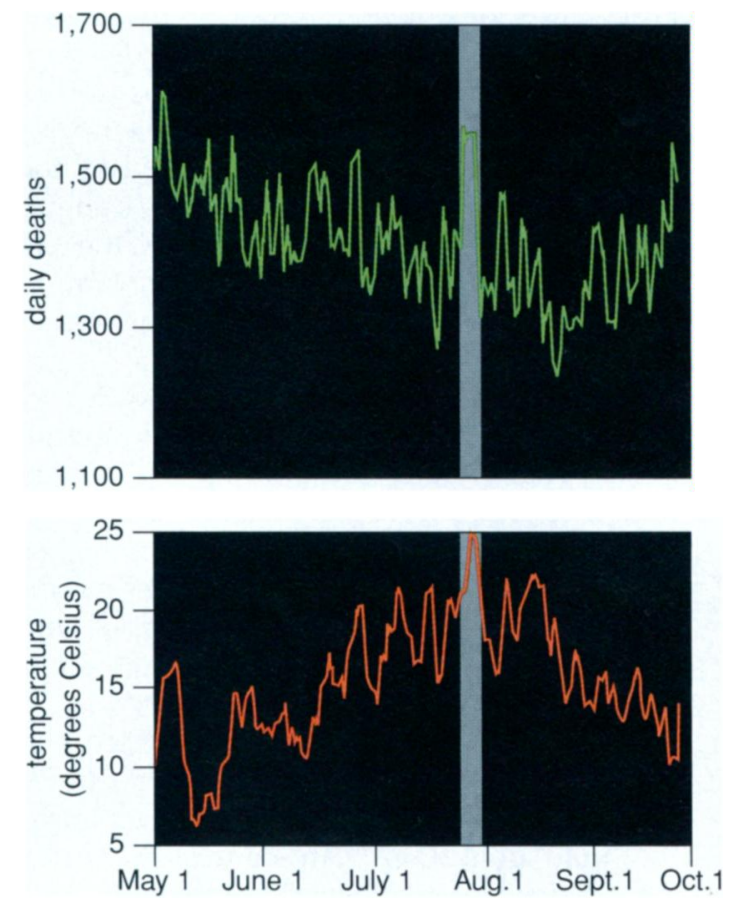

Figure 4. Sharp increase in the daily death rate corresponds to a heat wave in England during the summer of 1995. Populated urban areas typically experience the greatest number of heat-related deaths. (Adapted from Rooney et al. 1998.)

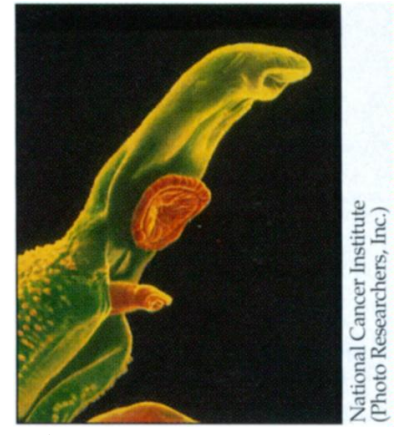

Schistosoma: the Bilharzia fluke 


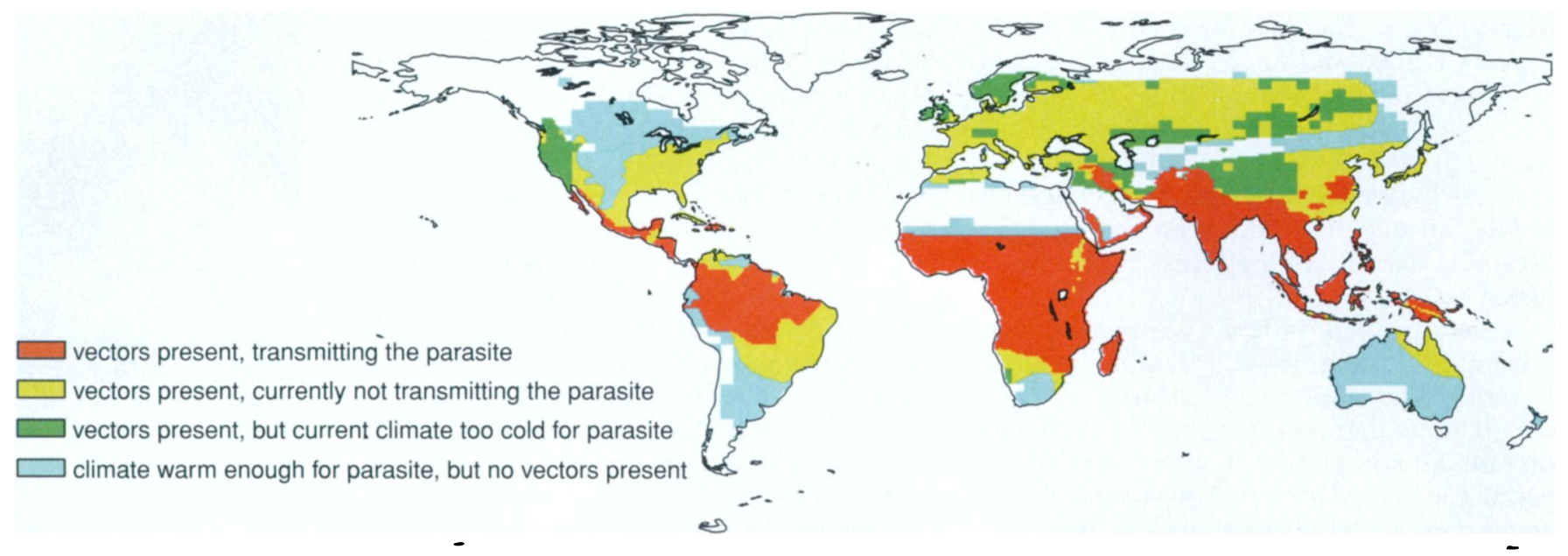

Figure 5. Potential for the spread of malaria is evident from the current distribution of the mosquito vector and the climatic limits of the parasite, as estimated for the species Plasmodium falciparum under conditions matching the average climate between 1961 and 1990. As of 1997, malaria is endemic (red) for only a fraction of its potential worldwide distribution.

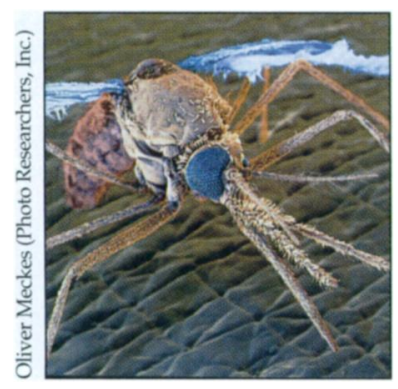

Anopheles: the malaria mosquito

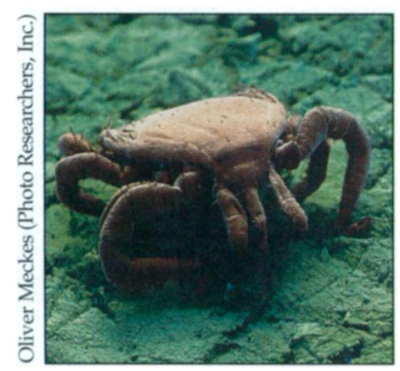

Deer tick: carrier of Borrelia, the Lyme disease bacterium number of infected snails declines sharply during the winter months. However, a temperature rise of a few degrees will ensure that schistosomiasis is transmitted throughout the year. So the burden of the disease, which is already great in this country, will increase further.

\section{Dengue}

Dengue, like malaria, is transmitted by mosquitoes. In this instance, however, the main vector is the Aedes aegypti mosquito (which also spreads yellow fever). The dengue virus is currently restricted to the tropics, roughly between 30 degrees South and 20 degrees North latitude. Here again the temperature affects the development of the mosquito and the virus as well as the frequency of mosquito bites. The temperature sensitivity of dengue is illustrated by the 1978-79 epidemic in Honduras. As dengue broke out in many parts of the country, the city of Tegucigalpa, where the average temperature is about 4 degrees lower than that of the coastal area, remained free of the disease.

In earlier times dengue was seldom found above 1,000 meters, but the disease was recently observed at 1,700 meters in Mexico. The dengue mosquito has been seen at 2,200 meters in Colombia, and the disease now occurs at higher elevations than ever before in the Andes mountains. A warmer climate may increase not only the elevations at which the disease occurs but also its northern and southern ranges.

Other factors have increased the incidence of dengue in recent years, and these are sometimes more important than climate: global urbanization, inadequate mosquito-control measures and increased international travel. Nevertheless, global warming may exacerbate the trend.

\section{Lyme Disease}

Until the 1980s, Lyme disease was sporadic. Now, however, thousands of people are infected every year. In the U.S. it is the most important vector-borne infectious disease. Lyme disease can cause headache, fever, back pain, tiredness and even damage to the brain and the heart. The behavior of the ticks that spread the disease is directly influenced by the climate. The spread of Lyme disease is complicated, however, because the tick's life cycle depends on other animals, such as mice, birds and deer. The distribution of these animals also depends on the climate in complex ways. We may not be able to say how the disease will spread, except to say that climatic change will probably modify its distribution.

\section{Water-Borne Diseases}

Changes in the amount of precipitation will also accompany the temperature changes to a warmer world. Many disease-causing organisms require water for survival, and increases in rainfall and flooding will encourage their wider distribution. Higher temperatures will increase their chances of survival. Various bacteria (Salmonella and Shigella), viruses (rotavirus) and protozoa (Giardia and Cryptosporidium) can cause diarrhea, which kills more than 3 million children every year.

The threat of fatal diarrhea is greatest where sewage systems and the availability of drinking water leave something to be desired. Poor countries are the most vulnerable and often experience diarrhea epidemics after heavy flooding. (Ironically, periods of drought can also wreak havoc as people are forced to use contaminated water sources.) Even in wealthier parts of the world drinking water can be contaminated after a flood.

The quality of above-ground water supplies can also be influenced by the warming of the earth. Some parts of Australia experience a seasonal incidence of meningitis, caused by the amoeba Naegleria fowleri. This amoeba reproduces during the summer in pipes that carry 


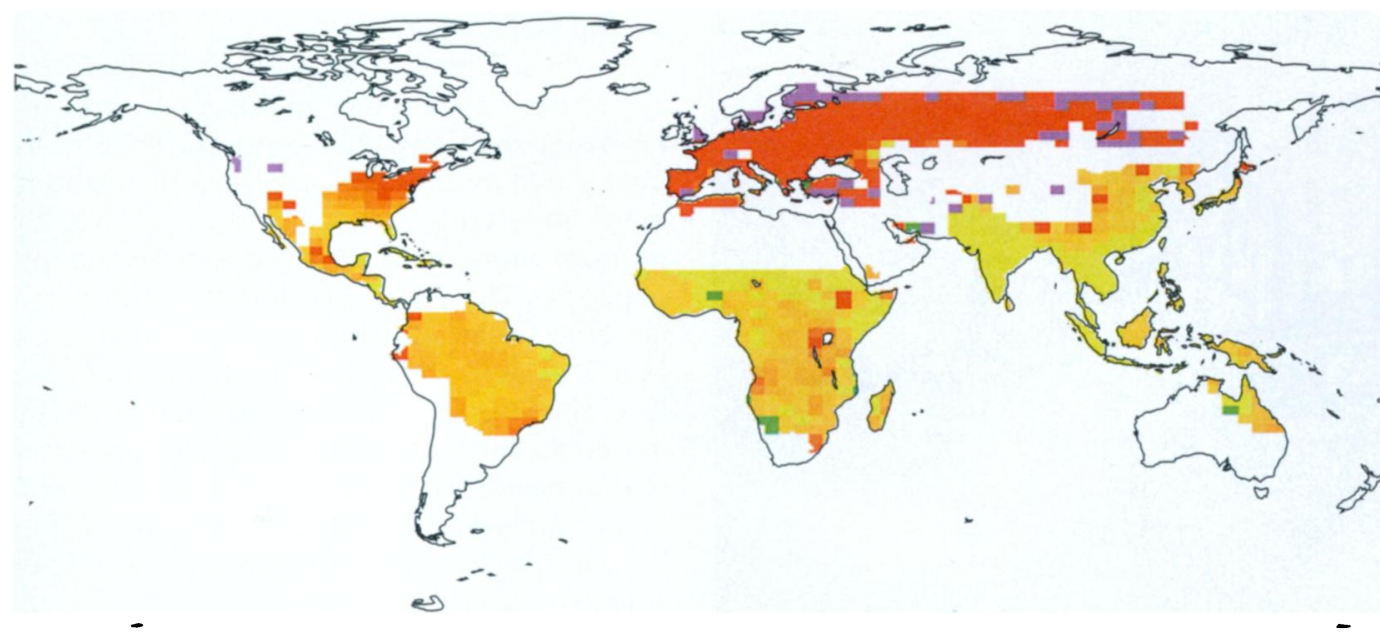

Figure 6. Malaria risk by the year 2020 will nearly double (red) in many parts of the world if the climate shifts as anticipated. The changes depicted here are based on the average climate from 1961 to 1990 and the climate-change scenario projected by a Hadley Climate Center model (HadCM3); other factors that could influence the situation are not considered. (Courtesy of Pim Martens.)

water above the ground. A higher average temperature may aggravate the problem. The effect of climate change on other water bodies-both natural (rivers, lakes, swamps) and artificial (irrigation systems, reservoirs) - will alter the distribution of water-borne diseases.

\section{Food-Borne Diseases}

Eating contaminated food is also a major cause of diarrhea. Even though refrigeration has sharply reduced infections from food, the number of diseases that can be caught from food remains strongly related to temperature fluctuations. Several paths are involved. For example, higher temperatures promote the survival of flies and cockroaches, which can transfer pathogens from feces to food. Warm temperatures (about 30 degrees) also promote the growth of the bacterium that causes botulism (Clostridium botulinum).

The contamination of edible fish and shellfish with biotoxin-producing plankton is also influenced by the climate. These biotoxins can produce paralysis and diarrhea. An increase in water temperature and sunlight, changes in the ocean currents and the $p \mathrm{H}$ of the water will undoubtedly alter the production of planktonand thus contaminated fish.

A changing climate is also likely to alter the spread of the cholera bacterium, Vibrio cholerae, which has recently returned to South America after a century of absence. In the late 1980s, a ship from the Far East discharged its ballast water (contaminated with cholera bacteria) into the harbor of Lima, Peru. People became sick after eating raw shellfish infected with the bacterium. In 1991, a cholera pandemic reached the U.S., infecting nearly half a million people. The spread of the bacterium has been linked to an algal bloom in coastal waters that were warmer than usual (partly a result of the El Niño effect).

\section{Malnutrition}

Currently malnutrition is primarily a matter of poverty. Although the world's production of food is sufficient to feed the global population, 800 million people are chronically underfed because they cannot afford to buy food. But the climate also has major impacts on agricultural harvests: Heat waves, droughts, floods and cy- change in risk factor for malaria by the year 2020
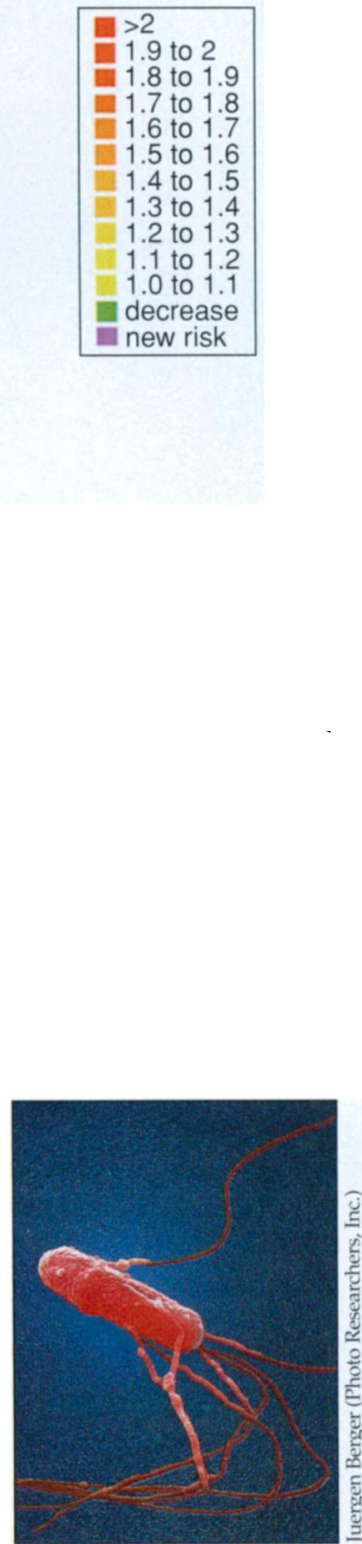

Salmonella: a bacterial cause of food and water poisoning

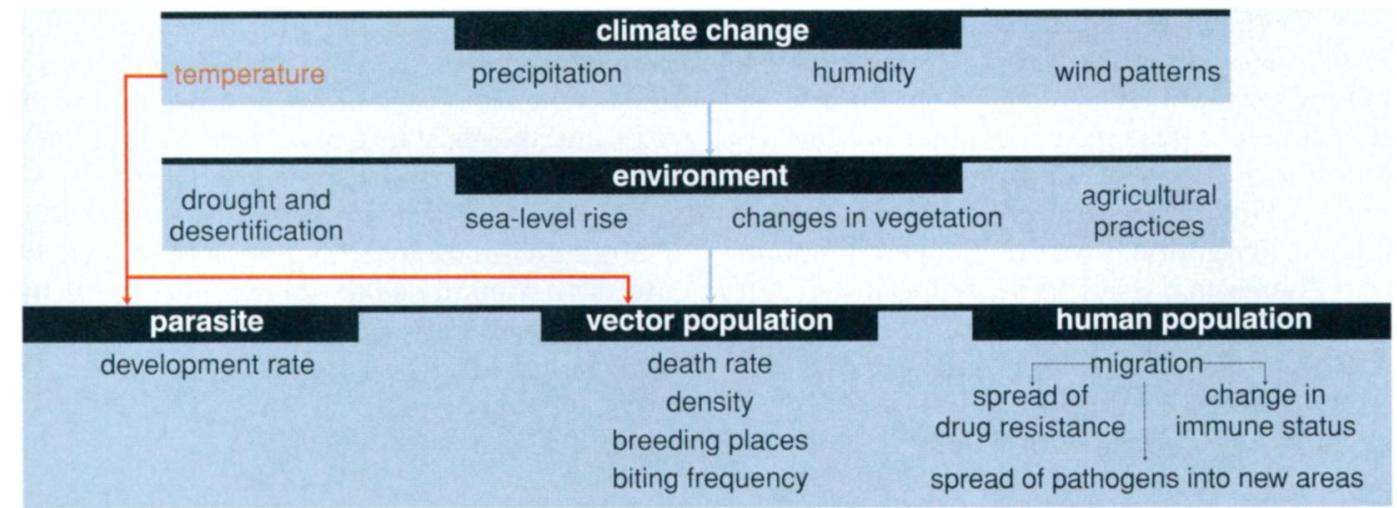

Figure 7. Climate change has complex consequences for the spread of vector-borne diseases, indirectly affecting the parasite, the vector population and the human population through climate-induced changes in the environment (blue arrows). Temperature changes will also directly affect the parasite and the vector population (red arrows). 


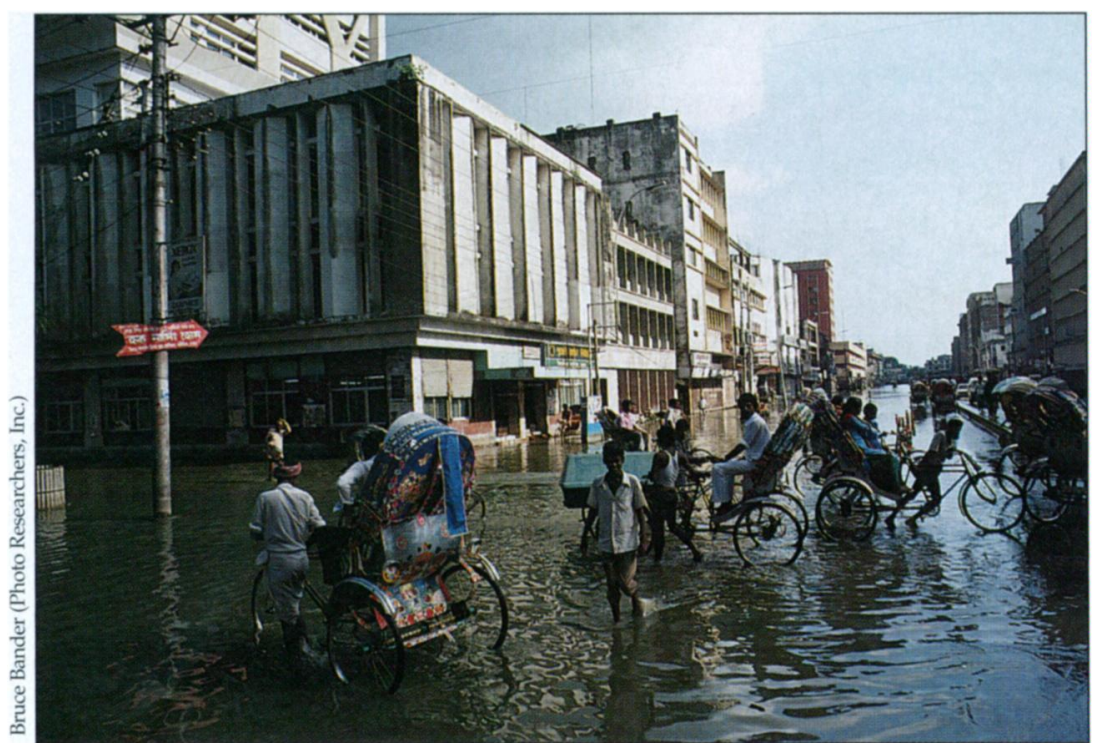

Figure 8. Floods will increase in susceptible areas in the next century if sea levels rise as projected. This scene in Bangladesh may be repeated with greater frequency.

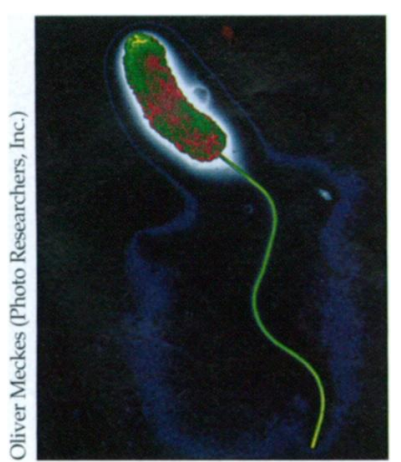

clones reduce agricultural harvests. In 1998, for example, a heat wave and a drought in North America led to a 30 percent decline in grain yields, resulting in a global rise in the price of grain. The harshest effect of such disturbances is on the poorer countries, which can buy less grain with their limited funds in times of need.

Yet the global consequences are not so straightforward. It is true that the current levels of rainfall are inadequate in many developing countries, with vulnerable areas located in a zone running from Brazil to China. A reduction in this scanty amount of precipitation could Vibrio cholerae: the cholera bacterium
Rising Sea Levels

According to some estimates, the sea level may rise about half a meter in the next centuryfar faster than any change in sea level in the past 1,000 years. Such a rise will inundate many low-lying areas, leading to destruction of crops along coasts and uprooting millions of people. The coast of Bangladesh, the Egyptian Nile Delta and some islands (such as the Maldives) will probably be inundated if the sea level rises merely 50 centimeters. Other low-lying areas, such as eastern England and parts of Indonesia, are also vulnerable. A number of major cities-Bangkok, Calcutta and Shanghai-in low-lying river basins are also vulnerable to a rise in sea level.

The forced removal of people from inundated areas will increase the likelihood of an outbreak of infectious diseases. The salt-water malaria mosquito, Anopheles sundaicus, will be able to penetrate farther inland. Freshwater supplies may be contaminated with salt water, leading to a decline in the availability of drinking water. Yields from shrimp farms and freshwater fisheries in small rivers and lakes will decline.

\section{Storms}

Changes in weather variability may effect the frequency and severity of extreme weather events, such as droughts, floods and storms. However, some of these relationships remain very uncertain. Storms may ensure that beneficial conditions are created for certain disease vectors. One can observe an increase in many vector-borne infectious diseases in the months after a hurricane in the Caribbean. Storms will also damage the infrastructure, leading to a lessthan-adequate response to an epidemic. those countries. On the other hand, yields in countries with moderate or cold climates may increase as it becomes warmer. Moreover, aside from being a greenhouse gas, carbon dioxide is also needed for plant photosynthesis. The "fertilization effect" - where more atmospheric carbon dioxide results in faster plant growth-may also increase crop production.

Climate change can have other effects on the production of food. Warm, humid conditions encourage the development of molds and parasites that may harm yields. Certain diseases among farm animals will also be influenced by the climate. A rise in sea level will reduce the amount of arable land, and climatic changes will restrict the amount of water that is available for irrigation. Finally, changes to aquatic ecosystems may lead to a decline in harvests from the seas and lakes.

Despite these complex interactions, it is generally believed that a climate change will have negative consequences for global food production. The poor, economically underdeveloped countries will experience the greatest impact, and the number of malnourished people in these countries will probably increase.

\section{Complicating Factors}

Many factors will influence how a population's health responds to climate change. Poverty and inadequate medical facilities, the poor quality of sewage systems, the degree of malnutrition and population density are risk factors for an outbreak of infectious disease. The geographic distribution of diseases will change as migration, international trade and increased global mobility carry pathogens outside their current limits. The resistance of mosquitoes to insecticides and the resistance of bacteria to antibiotics will further govern the spread of disease.

All of these factors will interact with a changing climate in a nonlinear way, so their effects on human health are extremely difficult to quantify. Despite the uncertainties, there are increasing indications that a changed climate may be a major factor in the distribution of many diseases.

\section{What We Must Do}

Current projections of climatic effects on public health are mired in a great deal of uncertainty. 


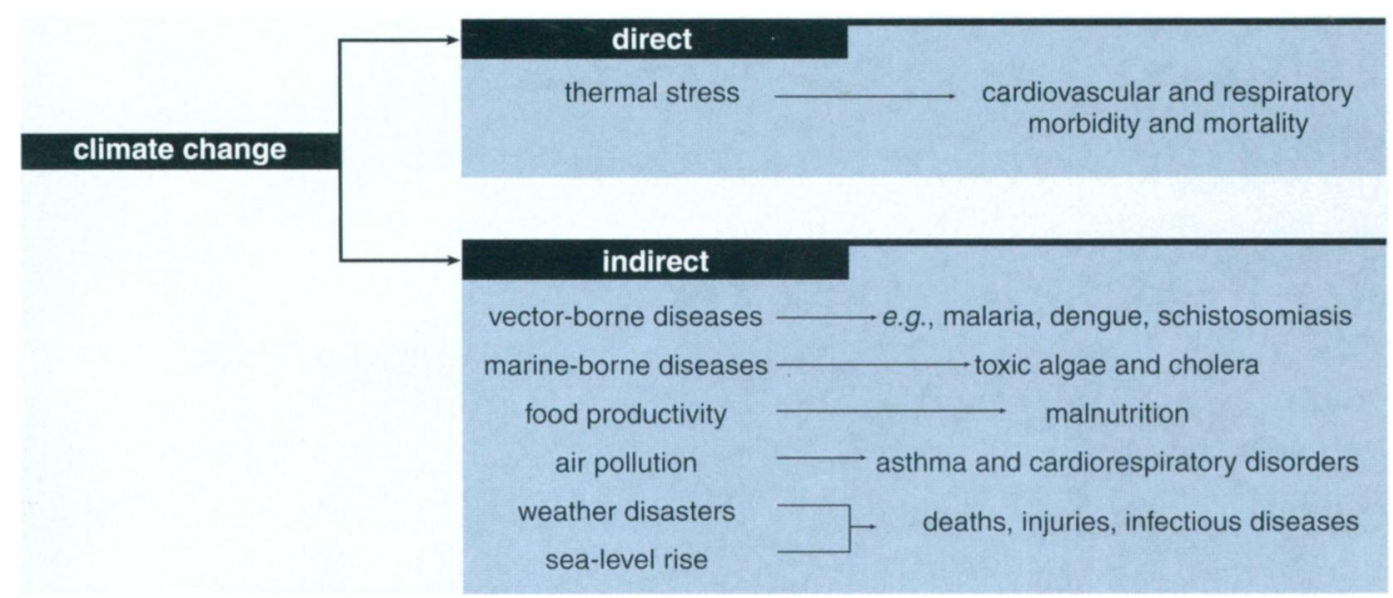

Figure 9. Changing climate will have direct and indirect effects on public health. The challenge for scientists is to determine the severity and direction of these effects.

Our understanding is simply too rudimentary to make any concrete statements about most of the issues mentioned in this review. Policy makers require a clearer estimation of these possible effects if they are to react adequately by means of adaptive and preventive strategies. This problem presents an open challenge to the scientific community.

Aside from empirical research, there is a need for new theoretical and conceptual approaches to estimating the effects of the changing global environment on human health. Epidemiology must develop new methods to represent the complex, nonlinear, long-term dynamics of climate and health.

Global observation systems need to be developed so that changes in health patterns or underlying factors can be seen at an early stage. For example, in vulnerable areas, a change in the incidence of malaria must be detected in good time, so that an adequate response can follow. The creation of such an early warning system, possibly with the use of satellites, will be useful even in the absence of climate change.

As we approach the 21st century, one of the most important tasks for medicine and the public-health sciences is to chart the possible health effects of climate change and other global environmental problems. The development of interdisciplinary research programs and integrated research methods will be essential.

In many developing countries the health care system and the infrastructure leave much to be desired. Even in the absence of a climate change, these will have to be improved to achieve better health in these countries. Given the potential seriousness of the effect that climate change may have on public health, an important way to minimize the effect will be to reduce the emission of greenhouse gases. There is an old saying in the health-care world: primum est non nocere- "above all, do no harm." It holds now as it always has. Prevention is better than cure.

\section{Acknowledgment}

The author would like to thank colleagues with whom he had discussions that led to his the writing of this article. In particular, he thanks Marjolein van Asselt, Jack Raes and Wouter de Groot, who provided comments on earlier versions of the manuscript.

\section{Bibliography}

IPCC. 1998. The Regional Impacts of Climate Change-An Working Group II, ed. R. T. Watson, M. C. Zinyowera, R. H. Moss and D. J. Dokken. New York: Cambridge University Press.

Levins, R., T. Awerbuch, U. Brinkman et al. 1994. The emergence of new diseases. American Scientist 82:52-60.

Martens, P. 1998. Health and Climate Change: Modelling the impacts of global warming and ozone depletion. London: Earthscan Publications.

McMichael, A. J., A. Haines, R. Slooff and S. Kovats. 1996 Climate Change and Human Health: An Assessment Prepared by a Task Group on Behalf of the World Health Organization, the World Meteorological Organization and the United Nations Environment Programme. Geneva: World Health Organization.

McMichael, A. J. et al. 1996. Human population health. In Climate Change 1995: Impacts, Adaptations, and Mitigation of Climate Change: Scientific-Technical Analysis, ed. R. T. Watson, M. C. Zinyowera, R. H. Moss and D. J. Dokken. New York: Cambridge University Press. pp. 563-584.

Patz, J. A., P. R. Epstein, A. B. Thomas, A. Burke and J. M. Balbus. 1996. Global climate change and emerging infectious diseases. The Journal of the American Medical Association 275:217-223.

Rooney, C., A. J. McMichael, R. S. Kovats and M. Coleman. 1998. Excess mortality in England and Wales, and in Greater London, during the 1995 heatwave. Journal of Epidemiology and Community Health 52:482.

Links to Internet resources for further exploration of "How Will Climate Change Affect Human Health?" are available on the American Scientist Web site:

http://www.amsci.org/amsci/articles/ 99articles/martens.html Assessment of Vulnerability. A Special Report of IPCC

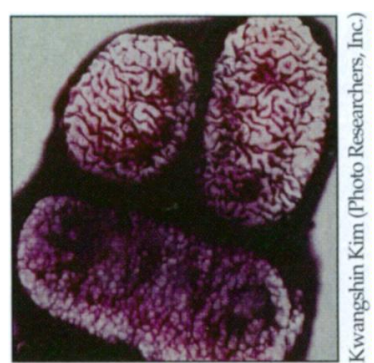

Shigella: a bacterial cause of dysentery 